\title{
The Evaluation of School Administrators' Views on the Need for Professional Development of Teachers regarding the Use of Technology in Physics Classes*
}

\author{
Gurcan $\mathrm{Uzal}^{1}$, Aytekin Erdem ${ }^{1}$ \\ ${ }^{1}$ Vocational School of Technical Sciences, Tekirdag Namik Kemal University, Tekirdag, Turkey \\ Correspondence: Gurcan Uzal, Vocational School of Technical Sciences, Deparment of Electronics and Automation, \\ Tekirdag Namik Kemal University, 59030 Suleymanpasa-Tekirdag, Turkey.
}

Received: January 3, 2020

doi:10.11114/jets.v8i4.4675
Accepted: February 17, 2020

Online Published: February 20, 2020

URL: https://doi.org/10.11114/jets.v8i4.4675

\begin{abstract}
The aim of the study is to investigate the school administrators' views on the professional development needs of teachers regarding the use of technology in physics classes. The participants of the study were 121 executive teachers from the city of Kocaeli. The data for the research was obtained using the survey model and was compiled with the help of a five point Likert type scale. The data collected by a scale with the reliability coefficient of 0.92 were analyzed using descriptive and inferential statistical techniques. As a result of the analysis, it was found that the administrators completely agreed with the use of the LCD panels in the teaching of physics subjects, while only agreeing with the other items. In addition, the opinions of school administrators regarding the professional development needs of teachers for the use of technology in physics classes does not differ according to demographic characteristics, but significantly do however, according to gender and experience. In light of the results, recommendations were made for researchers, administrators and the Ministry of National Education.
\end{abstract}

Keywords: school administrator, teacher, physics assisted by technology, in-service training

\section{Introduction}

Today in our country, the importance of the existence of applications and of the extensive use of technology in the education sector has been on the rise [Aziz, 1982; Cagiltay, Cakiroglu, Cagiltay \& Cakiroglu, 2001; Ministry of National Education (MNE), 1999; MNE, 2012; Odabas, 2004; Tekin, 1996]. One of the important projects in this respect is the 'Enhancing Opportunities and Improving Technology (Fatih)' Project. This project was initiated with five main objectives: building a hardware and software infrastructure, supplying and managing educational e-content and providing in-service training for teachers on the efficient use of computer technology (IT) [MNE, 2012]. With the implementation of the Fatih Project, high schools were equipped with interactive (smart) boards, tablet PCs and multi-function printers. In addition, high speed and secure internet (VPN) were provided to all schools (Sarimanoglu-Ucar, 2018). It has been emphasized that, while teachers use these technologies in teaching physics, especially the interactive board to deliver lessons and display experimental visuals, students do not have many opportunities to use this device (Erdem, Uzal \& Saka, 2018). On the other hand, it has been observed that the competency of teachers regarding the integration of technology into physics classes is not yet at the expected level. It has been concluded that the technology competency of teachers could be improved through professional development activities. Therefore, it is necessary to determine the professional development requirements of teachers regarding the use of technology in physics teaching.

\subsection{Literature Review}

When computer software is used in physics classes; the concepts could be made more understandable prior to conducting the actual experiments, abstract topics could be made more concrete, events that takes a long time in real life

\footnotetext{
* This study was supported by Research Fund of the Tekirdag Namık Kemal University, Project Number: NKUBAP.00.MB.AR.13. No.06.
} 
could be sped up, likewise, events that occur very quickly could be slowed down in order to be looked at more carefully and to have a better understanding which could therefore ensure that experiments that could not previously be performed for various reasons could be carried out and this could aid in storing data by determining measurements taken from experimental tools in laboratories in a more sensitive manner (Yigit \& Alev, 2017, Cited in: Akdeniz \&Yigit, 2001; Altin, 2003).

Using computers in collaborative environments is important in allowing students to be responsible for their own learning and also to enabling learning through discussion (Yigit \& Alev, 2017). It is stated that learning activities carried out in technology assisted environments increase the students' interest and success in physics classes (Yenice, 2003; Yigit, 2004; Cepni, Tas \& Kose, 2006).

Use of Information and Communication Technology (ICT) while teaching physics provides a good opportunity to increase knowledge, brings the learner together with new sources of knowledge and contributes to the structuring of knowledge, facilitates the effective presentation of information, supports students' understanding of visual concepts, enables individual learning, increases the efficiency of the learner and teacher, provides an opportunity for a constructivist learning environment, directs towards the production of student-centered activities, encourages cooperative learning and increases students' high level thinking skills, leading them to active learning (Yigit \& Alev, 2017, Cited in: Alev, 2003). As can be understood from the previous paragraphs, the importance of taking advantage of the opportunities provided by ICT in the teaching of physics subjects has been increasing. For this reason, it is necessary for teachers to bring the opportunities offered by ICT into the classroom and establish the integration of technology in physics classes.

The importance of teachers in education is an undeniable fact due to the fact that they are at the center of the learning process. Furthermore, teachers are expected to educate qualified individuals who are then needed by their country to take responsibility for the country's development. In line with this responsibility, teachers are required to direct their teaching processes, taking in to account technological changes and developments. In this aspect, it has been emphasized that teachers need to continuously learn and develop themselves in their profession and continue their proficiency throughout their lives (Ersoy, 1992; Ersoy, 2002). Glatthorn (1995) describes the professional development of the teacher as self-improvement in the teaching profession through the continuous acquirement of experience and attainment of skills in the implementation of their profession (Jacobs, 2012). Students will be able to acquire the knowledge and skills used extensively in the twenty-first century only when the professional development of teachers is carried out according to current criteria. It is crucial that periodic and effective in-service training activities in line with the MNE, which will be conducted together with universities and non-governmental organizations, are maintained, and which are parallel to the individual professional development of teachers (Jacobs, 2012, Cited in: Reimers, 2003).

Professional development activities to be prepared in order to improve the technological competencies of teachers should be implemented according to the relevant field and should be planned taking in to account the characteristics of the teaching field, the technology that teachers need and their connection to this technology. As stated in previous studies (Buldu, 2014; Culyer, 1984; Henning, 1994; Ruba, 1985; Yigit, Bulbul \& Bursal, 2008) the importance of first identifying the requirements must be taken in to account before the professional development activities are carried out. In this respect, it is expected that while the technological competencies and professional development needs of teachers are investigated, internationally accepted criteria such as the National Educational Technology Standard (NETS) will be taken in to consideration (Dag, 2016). It is believed that while the necessity of professional development is being analyzed, obtaining the views of teachers, school administrators and students on this issue will increase the efficiency of professional development activities.

The following are some of the studies in domestic literature that investigate teacher and manager views on the professional development requirements of teachers use of technological devices and products in the context of the Fatih Project. In a study conducted on the Fatih Project implemented in high schools in order to examine the views of school administrators, it was understood that the school administrators claim teachers' professional development activities should be ongoing (Kalelioglu \& Altin, 2013). One of the main objectives of the Fatih Project is to provide professional development to teachers (MNE, 2012). However, typically, a fundamental issue of professional development is the inability to respond to the needs of teachers (Zhang, Parker, Koehler \& Eberhardt, 2015; Cited in: Borko, 2004; Rotherham et al., 2008). In order for professional development activities to be fruitful it has been determined that the needs analysis be completed beforehand, that training activities be practise based, also the activities must be evaluated, next, whether or not the teachers carry the knowledge and skills obtained in the workshops to the classroom be determined and finally that the stages are monitored. The impact of school administrators on the professional development of teachers is quite significant. School Administrators can influence teachers' learning in four areas. They are as follows: 1. Leadership as an educational leader and learner, 2. Developing, designing and establishing the learning environment, 3. Direct participation in the content of professional development and 4. Assessment of 
professional development results (Bredeson, 2000).

The success of innovative approaches to education, in particular, the use of technology in classrooms, depends greatly on the environment and organization of the school and on the attitude of the school administrator towards proposed changes. The school administrator is expected to take a leading role in helping teachers adopt technology-based innovations that support learning and teaching at their school. The administrator is the foundation upon which teachers can develop (or either be suppressed) [Peled, Kali \& Dori, 2011].

School administrators, who are required to lead technology in the learning environment, are expected to play an important role in the acknowledgement, adoption and maintenance of innovations to be used in education (Elliott \& Mihalic, 2004). It is thought that school administrators could pursue the school-wide Positive Behavior Support [SWPBIS(School-Wide Positive Behavior Support)] Model (Chitiyo \& May, 2018) through the integration of technology into education if they fulfill these roles. In the study, which examined the factors affecting the sustainability of SWPBIS, school administrator support was identified as an important factor. (Chitiyo \& May, 2018, Cited in: Pinkelman, McIntosh, Rasplica, Berg \& Strickland-Cohen, 2005).School administrators are seen as the most critical people to take responsibility for the acquiring of computers and other related technologies and the effective use of these technologies at their schools. Some of the tasks to be undertaken are the acquiring of technology, the establishment of computer laboratories, the organization of educational activities for teachers in the field of new technologies, the recruitment of teachers already experienced in the field of current technology and the effective use of technology in school administration (Turan, 2002). They suggest that if teachers perceive school administrators to value and support the use of technology, technology will become more commonly valued and integrated in to the classroom (Alghamdi \& Prestridge, 2015). In order for the ICT to be integrated effectively into classes in educational institutions, school administrators must first increase their own ability to use technology and support their teachers in this respect (Wilmore \& Betz, 2000).

Studies conducted in our country following the implementation of the Fatih Project attempt to put forward the opinions of school administrators and teachers on professional development needs necessary to integrate technology into their lessons (Ayvaci, Bakirci \& Basak, 2014; Banoglu, Madenoglu, Uysal, \& Dede, 2014; Ciftci,Taskaya \& Alemdar, 2013; Erdem \& Uzal, 2018; Genc \& Genc, 2013; Gorhan \& Oncu, 2015; Kalelioglu \& Altin, 2013; Kayaduman, Sirakaya \& Seferoglu, 2011; Ozkan \& Deniz, 2014; Saritepeci, Durak \& Seferoglu, 2016). However, no research exists in literature on the views of school administrators, who must lead teachers in technology, regarding the use of technology in physics classes and the necessity for professional development of teachers. It is believed that this study could address this gap. Since it has been assumed that providing professional development for teachers will contribute to the integration technology in physics classes, the problem of the research therefore gains importance with regard to the findings that will be obtained at the end of this study. The aim of this study is to determine the school administrators' views on the professional development needs of teachers in technology-assisted instruction of physics.

\subsection{Limitations of the Study}

This research is limited to 121 administrative teachers at selected high schools and their answers to the questions in the data collection tool in the province of Kocaeli in the 2014-2015 academic school years. The opinions of participants who chose not to participate in the study, or whose participation was not provided, could have provided more useful information. Furthermore, the sample included in this study may not adequately represent the population. If the sample could have been made up of a larger number of participants, the participants' views on the professional development requirements required by physics teachers to integrate technology into education might have been different. Despite these restrictions, this research highlights some valuable thoughts on the professional development that physics teachers will need to use technology in their lessons from the point of view of school administrators.

Owing to the fact that the research participants were volunteers, it is possible that these participants had a positive attitude towards the integration of technology into physics courses, and therefore responded to the survey questions at a higher level than the managers who did not want to participate in the research would have responded.

\subsection{Research Questions}

School administrators are considered to have an important role in the adoption, implementation and maintaining of the implementation of the technology to improve student success in physics classes which are difficult for them to understand (e.g., Robinson \& Haugan, 2008). How the positive behavior support model applied by school administrators throughout the school will affect student success in technology-assisted physics classes, could be a potential research topic for physics educators and education administrators. This research could be considered and utilized as a preliminary study for the research in question.

In line with the stated views, the answers to the following questions were investigated in order to reveal the opinions 
and differences of the teachers regarding the need for professional development in technology-assisted physics instruction according to the individual characteristics of the school administrators.

1) At what stage are the school administrator's views on the professional development needs of teachers regarding the use of technology in physics courses?

2) Do the views of school administrators regarding the professional development needs of teachers on the use of technology in physics classes differ according to individual characteristics (gender, level of education, age, teaching experience, managerial experience, use of and ability to use technology)?

\section{Method}

\subsection{Research Design}

The research was conducted with a survey model. This model is one of the quantitative research methods, a form of research that aims to describe a situation, which was either previously formed or is currently in effect, in the form as it exists. An individual, subject or object is examined as it exists and an effort is made to reach a conclusion (Karasar, 1999, 77; Cepni, 2014, 72).

\subsection{Participants}

In the 2014-2015 academic year, there were 384 administrators working in high schools in Kocaeli city, and 121 administrators (principals and vice principals) who responded voluntarily to the scale. The error resulting from the sample number of the study performed was calculated as $6.20 \%$ at a $90 \%$ confidence level for 121 samples.

\subsection{Data Collection Tool}

In order to compile data on the topic from participating school administrators, a five-point Likert type, ten-question scale was used, containing several articles (views and trends) and composed by researchers, and its characteristics are as follows.

2.3.1 SAV_NPDTTAPI (School Administrator Views on the Need for the Professional Development of Teachers on Technology-Assisted Physics Instruction) Scale

This scale consists of 10 items collected under two factors, covering administrative teachers' views on the need for professional development in technology-assisted physics instruction. These are the articles under the titles "effective use of technological devices and assessment-evaluation criteria" and "technology-assisted physics instruction and performance of experiments." The overall model data compliance indices of the scale are as follows; $\chi 2(34)=120.00$, $\mathrm{p}<0.001, \chi^{2} / \mathrm{DF}=3.529, \mathrm{CFI}=0.946, \mathrm{SRMR}=0.0807$ and RMSEA $=0.145(90 \%$ confidence interval $0.117-0.173)$. The reliability coefficient of the scale is 0.92 . The items on the scale developed are rated as follows "[1] Strongly disagree", "[2] Disagree", "[3] Undecided", "[4] Agree", "[5] Strongly agree."

The SAV_NPDTTAPI scale does not contain any reverse encoded material and the lowest total score to be determined, as a result of the measurement, is 10 while the highest total score is 50 . There are seven items under the factor of "effective use of technological devices and assessment-evaluation criteria" and three items under the factor of "technology-assisted physics instruction and performance of experiments." The distinguishing power of these articles varies between 0.603 and 0.782 . Whether the measurement tool to be used would be suitable or not to collect the necessary data for the purpose was determined by obtaining an expert's opinion.

\subsection{Analysis of the Data}

The SPSS 15.0 package program was utilized in the descriptive and inferential analysis of the data.

In order to determine whether the raw scores obtained from the data collection tool show normal distribution, central spread criteria were found $(M=40.23 ; M d n=40.00 ; \operatorname{Mod}=40.00)$.

The raw scores obtained from the scale; first the $\mathrm{Z}$ score and then the $\mathrm{T}$ score were calculated and the raw scores were standardized and converted into equal ranges. $T$ scores were utilized in statistical analysis.

The results of the Kolmogorov-Smirnov and Shapiro-Wilk tests were used to determine if or not the scale scores were suitable for normal distribution. Following the test results, it was determined that the score distribution was not in accordance with the normal distribution. Therefore, the Mann Whitney U-Test for Independent Samples was used to determine if there was a difference between the averages of two groups and the Kruskal-Wallis H-Test for Independent Samples was used for groups of more than two. 


\section{Results}

The data was compiled using a five point Likert-type scale with the contribution of 121 volunteer administrative teachers. Descriptive and inferential statistical techniques were used in the research and the analysis of the data was completed in the SPSS package program.

\subsection{Demographics of School Administrators}

In order to obtain information on the background of the participating administrators, some questions were asked and the results have been summarized below.

Among the 121 school administrators surveyed; 99 (\%81.8) percent consisted of males and 22 (\%18.2) of females; when the education levels of the administrators were examined it could be seen that $90(\% 74.4)$ were graduates with bachelor's degrees and 31 (\%25.6) with master's degrees; when seniority was examined, 32 (\%26.4) had 0-11 years, 32 (\%26.4) had 12-17 years, 37 (\%30.7) had 18-23 years and $20(\% 16.5)$ had a minimum seniority of 24 years; looking at the experience of administrators; 65 (\%53.7) of the administrators had 0-5 years of experience, 31 (\%25.6) had 6-11 years and 25 (\%20.7) had a minimum of 12 years of managerial experience; finally in terms of use of technology and technological skills, 44 (36.4\%) had some, 66 (54.5\%) had moderate, and $11(9.1 \%)$ had good technological skills.

\subsection{Technological facilities and their Use in Schools}

\subsubsection{Computer and Use-Utilization}

Out of 121 school administrators, 14 school administrators stated that there were no computers at their schools, while 107 school administrators stated that there were computers at their schools. Out of the 107 (100\%) school administrators who stated that they had computers, $3(2.8 \%)$ claimed they do not make any use of the computers, 7 $(6.5 \%)$ make little use of the computers, 39 (36.5\%) make some use of the computers and $58(54.2 \%)$ highly benefit from the computers.

\subsubsection{Physics Software and Use-Utilization}

109 school administrators stated that there was no physics software (Interactive Physics, etc.) at their schools, while 12 administrators stated that there was. From the $12(100 \%)$ school administrators who stated that they had Physics software, $5(41.7 \%)$ claimed to make little use of the physics software, $6(50.0 \%)$ claimed to make some use of it, and 1 $(8.3 \%)$ claimed to highly benefit from it.

\subsubsection{Mobile Science Laboratory (Nova 5000, etc.) and Use-Utilization}

106 school administrators stated that no Mobile Science Laboratories (Nova 5000, etc.) existed at their schools, while 15 claimed that they had laboratories. From the 15 school administrators who indicated that they had Mobile Science Laboratories (Nova 5000, etc.) 15 (100\%), $5(33.3 \%)$ claimed to make no use of the Mobile Science Laboratory, 5 $(33.3 \%)$ claimed to make little use of them, $4(26.7 \%)$ claimed to make some use of them and 1 (6.7\%) claimed to highly benefit from the Mobile Science Laboratories.

\subsubsection{Tablet PC and Use-Utilization}

46 school administrators stated that there were no Tablet PCs at their schools, while 75 school administrators stated that there were. Out of the $75(100 \%)$ school administrators, $5(6.7 \%)$ claimed to make no use of Tables, $10(13.3 \%)$ claimed to make little use of them, $34(45.3 \%)$ claimed to make some use of them, and $26(34.7 \%)$ claimed to highly benefit from Tablet PCs.

\subsubsection{LCD Panel (interactive board) and Use-Utilization}

13 school administrators stated that there were no LCD panels (interactive boards) in their schools, while 108 school administrators stated that there were. Of the 108 (100\%) school administrators who stated that they had LCD panels, 9 $(8.3 \%)$ claimed to make no use of the LCD panels, 7 (6.5\%) claimed to make little, $29(26.9 \%)$ claimed to make some and $63(58.3 \%)$ claimed to highly benefit from them.

\subsubsection{Guidelines to Technology-Assisted Physics Experiments and Use-Utilization}

102 school administrators stated that there were no guidelines for technology-assisted physics experiments at their schools, while 19 school administrators stated that there were. Out of the $19(100 \%)$ school administrators who stated that there was a guide for technology-assisted physics experiments, $2(10.5 \%)$ stated to make no use of it, $4(21.1 \%)$ stated to made some, $10(52.6 \%)$ stated to make little, and $3(15.8 \%)$ stated to highly benefit from the guide for technology-assisted physics experiments. 


\subsubsection{Technology Equipped Classrooms / Classrooms (Lab) and Use-Utilization}

It has been stated that while 51 administrator's schools did not have technology equipped classrooms (labs), 70 school administrators did. Out of the $70(100 \%)$ school administrators who stated that they had technology equipped classrooms (lab), 3 (4.3\%) stated to make no use of the technology equipped classrooms (lab), 15 (21.4\%) stated to make little, $31(44.3 \%)$ stated to make some, and 21 (30.0\%) stated to have highly benefitted from the technology equipped classrooms (lab).

\subsection{Data analysis and Results-I: Descriptive Statistics}

3.3.1 School Administrator Views on the Need for Teachers Professional Development in Technology-Assisted Physics Instruction

In order for administrators to determine the level of the professional development needs of teachers in technology-assisted physics instruction, according to the scores obtained from the SAV_NPDTTAPI scale; Table 1 shows the options and point ranges used in the scale evaluation.

Table 1 shows the scale in which options and limits are given, generated with the formula: gap width of the scale is "gap width = array width / number of groups to be completed."

Table 1. Scale options and score ranges obtained essentially for the evaluation of scale data

\begin{tabular}{cll}
\hline Points Allocated & Options & Point range \\
\hline 5 & Strongly Agree & $4.20-5.00$ \\
4 & Agree & $3.40-4.19$ \\
3 & Undecided & $2.60-3.39$ \\
2 & Disagree & $1.80-2.59$ \\
1 & Strongly Disagree & $1.00-1.79$
\end{tabular}

The average and standard deviation of School Administrators' views on the Professional Development Needs in Technology-Assisted Physics Instruction is displayed in Table 2.

Table 2. Average and standard deviation of Administrators' views on the Professional Development Needs in Technology-Assisted Physics Instruction

\begin{tabular}{|c|c|c|c|}
\hline $\begin{array}{l}\text { School Administrators' views on the Professional Development Needs } \\
\text { in Technology-Assisted Physics Instruction }\end{array}$ & Mean & $S D$ & $\begin{array}{l}\text { Degree of } \\
\text { Agreement } \\
\text { on Views }\end{array}$ \\
\hline \multicolumn{4}{|l|}{ Effective use of technological devices and assessment-evaluation criteria } \\
\hline Use of LCD panels (interactive board) in teaching course subjects & 4.20 & 0.74 & $\begin{array}{l}\text { Strongly } \\
\text { agree }\end{array}$ \\
\hline Technology-assisted constructivist learning approach & 4.14 & 0.64 & \multirow{6}{*}{ Agree } \\
\hline Technology-assisted project-based learning / teaching activities & 4.07 & 0.68 & \\
\hline Use of interactive (smart) boards effectively in classrooms & 4.06 & 0.86 & \\
\hline Assessment and evaluation criteria in technology-assisted instruction & 4.03 & 0.70 & \\
\hline Use of tablet PCs in physics classes and effective use of Tablet PCs & 3.84 & 0.90 & \\
\hline Use of Mobile Science Laboratory (Nova etc.) in instruction & 3.77 & 0.81 & \\
\hline \multicolumn{4}{|l|}{ Technology-assisted instruction of physics and performance of experiments } \\
\hline Basic knowledge and skills for technology-assisted physics instruction & 4.07 & 0.74 & \multirow{3}{*}{ Agree } \\
\hline Knowledge and skills to perform technology-assisted experiments & 4.05 & 0.72 & \\
\hline Use of physics class software in teaching / learning activities & 4.00 & 0.68 & \\
\hline
\end{tabular}

When the values in Table 2 are examined, under the factor "effective use of technological devices and assessment-evaluation criteria," it is observed that administrators strongly agreed with the view "LCD panel (interactive board) use in the instruction of class subjects $(M=4.20)$ " and agreed with the views "technology-assisted constructivist learning approach $(M=4.14)$," "technology-assisted project-based learning / teaching activities $(M=4.07)$," use of interactive (smart) boards effectively in classrooms $(M=4.06)$," "assessment and evaluation criteria in 
technology-assisted instruction ( $M=4.03)$," "use of tablet PCs in physics classes and effective use of Tablet PCs $(M=3.84)$ " and "use of Mobile Science Laboratory (Nova etc.) in instruction $(M=3.77)$."

It is understood that, under the factor "technology-assisted instruction of physics and performance of experiments," administrators agreed with the following views; "basic knowledge and skills for technology-assisted physics instruction $(M=4.07)$," "knowledge and skills to perform technology-assisted experiments $(M=4.05)$ and "use of physics class software in teaching / learning activities $(M=4.00)$."

It can be understood that administrators agreed on an average level of 4.00 (agreed) on the articles of the scale related to school administrator views on professional development needs of teachers on technology-assisted physics instruction. This result can be interpreted to show the agreement of school administrators on the items specified on the scale and that they are of the opinion that it is appropriate for teachers to receive the professional development training specified in the articles.

\subsection{Analysis of Data and Results-II: Inferential Statistics}

This section includes comments on whether the views of school administrators regarding teachers professional development needs in technology-assisted physics instruction differ according to individual characteristics.

From the normality test results of the scale scores by gender, it is understood that the score distribution of males $\left(D_{(99)}=0.166, p=0.000\right)$ is not in accordance with the normal distribution. ${ }^{1}$ The Mann-Whitney U-test for Independent Samples, which is a nonparametric test, was therefore applied.

Table 3. Mann-Whitney U-Test Results for the AV_NPDTTAPI scale scores according to gender

\begin{tabular}{lccccc}
\hline Gender & $\mathrm{n}$ & Rank Average & Rank Total & $\mathrm{U}$ & $\mathrm{p}$ \\
\hline Male & 99 & 64.05 & 6341.00 & 787.00 & .041 \\
Female & 22 & 47.27 & 1040.00 & &
\end{tabular}

According to Table 3, there was a significant difference between the views of the administrators by gender regarding the professional development needs of teachers in technology-assisted physics instruction $(U=787.00, p<0.05)$. When rank averages are taken in to account, it is understood that the male administrator agreement on views regarding the professional development needs of teachers on technology-assisted physics instruction is higher than that of the female administrators. This result can be said to be due to the fact that male administrators wish to be more interested in the issue of technology-assisted physics instruction compared to female managers.

From the results of the test to determine the normal distribution of SAV_NPDTTAPI scale scores according to the level of education; it is understood that the score distribution of both undergraduate $\left(D_{(90)}=0.182, p=0.000\right)$ and graduate $\left(D_{(31)}=0.162, p=0.037\right)$ are not suitable for normal distribution. Therefore, the Mann-Whitney U-test for Independent Samples, which is a nonparametric test, was applied for unrelated measurements.

Table 4. The Mann-Whitney U-Test Results for the SAV_NPDTTAPI scale scores according to level of education

\begin{tabular}{lccccc}
\hline Education Level & $\mathrm{n}$ & Rank Average & Rank Total & $\mathrm{U}$ & $\mathrm{p}$ \\
\hline Undergraduate & 90 & 60.63 & 5456.50 & 1361.50 & .841 \\
Post Graduate & 31 & 62.08 & 1924.50 & &
\end{tabular}

Table 4 indicates that there was no significant difference among school administrator views on teachers professional development needs in technology-assisted physics instruction according to level of education $(U=1361.50, \mathrm{p}>0.05)$. According to this conclusion, it can be determined that both administrators with undergraduate and post-graduate education have the same perspective on the professional development needs of teachers in technology-assisted physics instruction.

According to age normality test results of scale scores; the score distribution of administrators aged $31-40\left(D_{(54)}=0.178\right.$, $p=0.000)$, aged 41-50 $\left(D_{(49)}=0.198, p=0.000\right)$ and aged 51 and over $\left(D_{(18)}=0.272, p=0.001\right)$, is not suitable for normal distribution. For this reason, the Kruskal Wallis H-test for independent Samples, which is a nonparametric test, was applied for unrelated measurements.

\footnotetext{
${ }^{1}$ When selected the group size is taken into consideration, $(\mathrm{n} \geq 51)$ Kolmogorov-Smirnov from the normality test results and $(\mathrm{N} \geq 50)$ Shapiro-Wilk test results should be taken into account (Buyukozturk, 2012, 42).
} 
Table 5. The Kruskal Wallis Test results for the SAV_NPDTTAPI scale scores according to age

\begin{tabular}{lcccccc}
\hline Age & $\mathrm{n}$ & Mean Rank & $\mathrm{df}$ & $\chi^{2}$ & $\mathrm{p}$ & Significant Difference \\
\hline Age 31-40 & 54 & 55.64 & 2 & 5.648 & .059 & None \\
Age 41-50 & 49 & 70.02 & & & & \\
Age 51 & 18 & 52.53 & & & & \\
and over & & & & & & \\
\hline
\end{tabular}

Table 5 shows that there is no significant difference according to the ages of administrators and their views on professional development needs of teachers in technology-assisted physics instruction $\left[\chi^{2}(d f=2, \mathrm{n}=121)=5.648, p>\right.$ 0.05]. However, when we look at the rank averages, it can be said that administrators in the 41-50 age group when compared to the other age groups, believe that teachers require more professional development requirements in technology-assisted physics instruction. It is thought that a statistically insignificant difference occurs because administrators in this age group are more experienced in education than administrators in the 31-40 age group and have a higher desire to learn and teach than administrators in the 51 and older age group.

Scale scores from normality test results based on teaching experience;

Score distribution of teaching experience according to administrators of 0 - 11 years $\left(D_{(32)}=0.200, p=0.002\right), 12-17$ years $\left(D_{(32)}=0.195, p=0.003\right), 18-23$ years $\left(D_{(37)}=0.189, p=0.002\right), 24$ and above years $\left(D_{(20)}=0.338, p=0.000\right)$ is not appropriate for normal distribution. For this reason, the Kruskal Wallis H-test for independent Samples, which is a nonparametric test, was applied for unrelated measurements.

Table 6. Kruskal Wallis test results of SAV_NPDTTAPI scale scores according to teaching experience

\begin{tabular}{lcccccc}
\hline Teaching Experience & $\mathrm{n}$ & Mean Rank & $\mathrm{df}$ & $\chi^{2}$ & $\mathrm{p}$ & Significant Difference \\
\hline 0-11 years & 32 & 63.22 & 3 & 4.244 & .236 & None \\
12-17 years & 32 & 55.14 & & & & \\
18-23 years & 37 & 68.92 & & & & \\
24 years and above & 20 & 52.18 & & & & \\
\hline
\end{tabular}

Table 6 shows that there is no significant difference according to teachers experience regarding school administrator views on professional development needs of teachers in technology-assisted physics instruction $\chi^{2}(d f=3, \mathrm{n}=121)=$ 4.244, $p>0.05$. It can be interpreted that this result is due to adaptation to technology of the low senior administrators through the pre-service training process and the senior administrators through participation in the in-service training activities.

The results of the test to determine the normal distribution of SAV_NPDTTAPI scale scores according to administrative experience indicate that the score distribution of school administrators with experiences of $0-5$ years $\left(D_{(65)}=0.161\right.$, $p=0.000), 6-11$ years $\left(D_{(31)}=0.210, p=0.001\right)$ and 12 years $\left(D_{(25)}=0.252, \mathrm{p}=0.001\right)$ are not suitable for normal distribution. For this reason, the Kruskal Wallis H-test for independent Samples, which is a nonparametric test, was applied for unrelated measurements.

Table 7. Scale scores of the Kruskal Wallis test results according to administrative experience

\begin{tabular}{lcccccc}
\hline Administrative Experience & $\mathrm{n}$ & Mean Rank & $\mathrm{df}$ & $\chi^{2}$ & $\mathrm{p}$ & Significant Difference \\
\hline 0-5 years & 65 & 56.22 & 2 & 6.123 & .047 & 6-11 years and 0-5 years \\
6-11 years & 31 & 74.32 & & & & \\
12 years and above & 25 & 56.90 & & & & \\
\hline
\end{tabular}

From Table 7 it can be understood that there is a significant difference between school administrators' administrative experience regarding views on professional development needs of teachers in technology-assisted physics instruction $\left[\chi^{2}(d f=2, \mathrm{n}=121)=6.123, p<0.05\right]$. To determine the source of the difference, a Mann-Whitney U-test was conducted amongst the groups. According to rank averages, it was found that those with 6-11 years of administrative experience were more likely to agree with views regarding professional development needs of teachers in technology-assisted physics instruction when compared to those with $0-5$ years and that the difference was significant.

The test results to determine the normal distribution of SAV_NPDTTAPI scale scores on the use of technology and technological skills indicate that the score distribution of administrators with little experience $\left(D_{(44)}=0.185, p=0.001\right)$, some experience $\left(D_{(66)}=0.202, p=0.000\right)$, high experience $\left(D_{(11)}=0.274, p=0.020\right)$ are not suitable for normal distribution. 
For this reason, the Kruskal Wallis H-test for independent Samples, which is a nonparametric test, was applied for unrelated measurements.

Table 8. SAV_NPDTTAPI scale scores of the Kruskal Wallis test results according to the use of technology and technological skills

\begin{tabular}{lcccccc}
\hline $\begin{array}{l}\text { Use of technology } \\
\text { technological skills }\end{array}$ & $\mathrm{n}$ & Mean Rank & $\mathrm{df}$ & $\chi^{2}$ & $\mathrm{p}$ & Significant Difference \\
\hline Little & 44 & 68.41 & 2 & 3.246 & .197 & None \\
Some & 66 & 56.23 & & & & \\
High & 11 & 59.95 & & & & \\
\hline
\end{tabular}

Table 8 shows that the scores the school administrators received on the SAV_NPDTTAPI scale do not differ significantly according to their use of technology and technological skills $\left[\chi^{2}(d f=2, n=121)=3.246, p>0.05\right]$. From this result, it is understood that administrator views on the professional development needs of teachers in technology-assisted physics instruction do not vary according to their use of technology and technological skills. This may be because administrators adequately monitor the physics teachers.

\section{Discussion}

The aim of the research is to determine the administrative opinions on the professional development needs of teachers regarding the use of technology in physics classes. In the study, school administrators believe that teachers need a high level of professional development in "using the LCD panel in teaching lesson subjects." The research carried out by Erdem \& Uzal (2017) to determine the professional development needs of teachers on the use of technology in physics classes also determined that teachers wanted to improve themselves regarding the use of LCD panels. In several studies, the source of the problems that arise throughout the use of interactive boards has been found to be due to the lack of knowledge and experience of teachers on this device (Coklar \& Tercan, 2014; Kayaduman, Sirakaya \& Seferoglu, 2011; Smith, Higgins, Wall \& Miller, 2005; Turel, 2012), therefore, it can be assumed that teachers will need professional development in this field. These results support the research results. The reason for this overlap may be that school administrators have observed that although teachers tend to use the LCD panels provided to schools by the Fatih Project, they have not yet been able to integrate this tool in to instruction in physics classes.

In the study, it is understood that school administrators agree on the professional development needs of teachers in the areas mentioned in the other nine articles of the scale $(M=3.40-M=4.10)$. These articles are as follows: technology-assisted constructivist learning approach, technology-assisted project-based learning/teaching activities, use of interactive (smart) boards effectively in classrooms, assessment and evaluation criteria in technology-assisted instruction, use of tablet PCs in physics classes and effective use of tablet PCs, use of mobile science laboratories (Nova etc.) in instruction, basic knowledge and skills for technology-assisted physics instruction, knowledge and skills to perform technology-assisted experiments and use of physics class software in teaching/learning activities. It is observed that constructivist and project-based learning approaches were introduced into the teaching programs of our country as of 2005. Numerous in-service training activities were carried out for teachers and school administrators by MNE, Universities and Non-Governmental Organizations regarding these issues. Due to the fact that school administrators possess ample knowledge and experience on these approaches, it is conceivable that they believe that using these approaches in technology-assisted physics instruction would be beneficial.

The reason that the administrators in the research state that teachers need professional development in the field of assessment and evaluation criteria in technology-assisted instruction, may be because they believe that the quality of instruction will increase with the effective use of technology in the field of assessment and evaluation. In the study, administrators believe that teachers need professional development to "utilize the tablet PCs in physics lessons and use tablet PCs effectively." In the research by Erdem \& Uzal (2017), teachers also need in-service training on how to use tablet PCs effectively. This finding supports the research finding. This overlap may be due to the fact that tablet PCs have not yet been used effectively in schools. It is stated that the tablets distributed to teachers and students through the Fatih Project are not used sufficiently in the lessons (Dursun, Kuzu, Kurt, Gullupinar, \& Gultekin, 2013; Isci \& Demir, 2015; Pamuk, Cakir, Ergun, Yilmaz \& Ayas, 2013). Since teachers have not received adequate in-service training on the effective use of tablets, it is conceivable that administrators became aware of this deficiency and are considering increasing the competency of teachers in this area.

In the research, administrators state that physics teachers have a need for professional development in the use of "Mobile science laboratory (Nova, etc.)" for use in education. Seeing that school administrators are of the opinion that in order for technology-assisted laboratory activities to be improved, the Mobile Science Laboratory must be utilized 
(Erdem \& Uzal, 2018), they can also be accepted to agree with this view.

In the study, administrators believe that competency of teachers must be improved in terms of basic knowledge and skills, knowledge and skills to perform technology-assisted physics experiments and the use of physics software for teaching/learning activities, in order to be able to use technology effectively in physics classes. In research by Erdem \& Uzal (2018), which aims to determine administrative views to improve technology-assisted physics instruction, participants proposed improving teachers' knowledge and skills in using technology in physics classes. This result supports the research result. This may be because administrators believe that the challenge of learning physics could be overcome with help of technology. Reason being, it is emphasized that the realization of technology-assisted teaching activities will increase the success of the students in therefore creating accomplishments in physics lessons that are difficult to understand and enable students to learn physics subjects meaningfully (Harwood \& McMahon, 1997; Kolcak, Mogol \& Unsal, 2014).

\section{Conclusion}

In this study to put forth administrative views on professional development needs of high school physics teachers in the instruction of the technology-assisted instruction of physics, it is understood that administrators completely agree that teachers need professional development in "the use of LCD panels (interactive board) for the instruction of class subjects." Furthermore, it has been deduced that administrators agree with the views supporting; the technology-assisted constructivist learning approach, technology-assisted project-based learning/teaching activities, the use of interactive (smart) boards effectively in classrooms, assessment and evaluation criteria in technology-assisted instruction, the use of tablet PCs in physics classes and the effective use of tablet PCs, the use of mobile science laboratories (Nova etc.) in instruction, basic knowledge and skills for technology-assisted physics instruction, knowledge and skills to perform technology-assisted experiments and, the use of physics class software in teaching/learning activities.

In the scope of the research carried out, the levels of the school administrators' views regarding the professional development needs of teachers in the use of technology in physics classes were determined and it revealed that these views differ significantly according to the gender of school administrators and their experience as school administrators.

In line with the results above, the following suggestions can be made.

- Assuming the study is in the form of a pilot survey, a survey involving a larger number of school administrators could be carried out. In addition, face-to-face interviews with the school administrators selected from the participants of the study could provide more in-depth information on the school administrator's views on the professional development needs of teachers in the use of technology in physics classes.

- School administrators in high schools should be given professional development training in the integration of technological resources in to experiments and classes at their schools as well as in the persuasion and informative stages on technology leadership issues.

- Workshops should be held with the participation of physics teachers and school administrators to determine the tasks that school administrators could undertake in technology-assisted physics instruction. The reports that would emerge as a result of these workshops should be shared with other school administrators and physics teachers.

- In order to increase the knowledge and skills of teachers to carry out technology-assisted physics experiment activities, school administrators should support teachers to carry out experiment guide development workshops in small groups.

\section{References}

Alghamdi, A., \& Prestridge, S. (2015). Alignment between principal and teacher beliefs about technology use. Australian Educational Computing, 30(1). Retrivied http://journal.acce.edu.au/index.php/AEC/article/view/52/pdf

Ayvaci, H. S., Bakirci, H., \& Basak, M. H. (2014). The evaluation of the problems emerging during the implementation process of the FATIH Project by administrators, teachers and students. Yuzuncu Yil University, Faculty of Education Journal, 11(1), 20-46.

Aziz, A. (1982). Radio and Television Education (1 ${ }^{\text {st }}$ Edition). Ankara: Ankara University Faculty of Education Center For Educational Research, Publication No: 2. Banoglu, K., Madenoglu, C., Uysal, S., \& Dede, A. (2014). An investigation of teachers' perceptions of the Implementation of the FATIH Project (Eskisehir Province Case). Journal of Educational Sciences Research, 39-58. https://doi.org/10.12973/jesr.2014.4os3a

Bredeson, P. V. (2000). The school principal's role in teacher professional development. Journal of in-service education, 26(2), 385-401. https://doi.org/10.1080/13674580000200114

Buldu, M. (2014). A proposal regarding the evaluation of teacher competence level and plans for professional 
development trainings. Journal of National Education, 44(204), 114-134.

Buyukozturk, S. (2012). Handbook of data analysis for the Social Sciences: Statistical research pattern, SPSS applications and interpretation (16 ${ }^{\text {th }}$ edition). Ankara: PEGEM A Publishing.

Cagiltay, K., Cakiroglu, J., Cagiltay, N., \& Cakiroglu, E. (2001). Teacher views on computer use in teaching. Hacettepe The Journal of University Education, 21(1), 19-28.

Cepni, S. (2014). Introduction to research and Project Studies ( $7^{\text {th }}$ Edition). Trabzon: Celepler Printing Company.

Cepni, S., Tas, E., \& Kose, S. (2006). The effects of computer-assisted material on students' cognitive levels, misconceptions and attidues towards science. Computers \& Education, 46(2), $192-205$. https://doi.org/10.1016/j.compedu.2004.07.008

Chitiyo, J., \& May, M. E. (2018). Factors predicting sustainability of the schoolwide positive behavior intervention support model. Preventing School Failure: Alternative Education for Children and Youth,62(2), 94-104. https://doi.org/10.1080/1045988X.2017.1385446

Ciftci, S., Taskaya, S. M., \& Alemdar, M. (2013). Classroom teachers' views on FATIH Project. Primary School Education Online, 12(1), 227-240.

Coklar, A. N., \& Tercan, I. (2014). Opinions of teachers towards the use of smartboards. Elementary Education Online, $13(1), 48-61$.

Culyer, R. (1984). Chapter I Programs: Problems and Promising Solutions. The Clearing House: A Journal of Educational Strategies, Issues and Ideas, 57(5), 231-238. https://doi.org/10.1080/00098655.1984.11478141

Dag, F. (2016). Examination of the Professional development studies for the development of technological competence of teachers in Turkey in the context of lifelong learning. International Journal of Human Sciences, 13(1), 90-111. https://doi.org/10.14687/ijhs.v13i1.3523

Dursun, O. O., Kuzu, A., Kurt, A. A., Gullupinar, F., \& Gultekin, M. (2013). Views of school administrators' on FATIH projects pilot implementation process. Trakya University Faculty of Education Journal, 3(1), 100-113.

Elliott, D. S., \& Mihalic, S. F. (2004). Issues in disseminating and replicating effective prevention programs. Prevention Science, 5, 47-53. https://doi.org/10.1023/B:PREV.0000013981.28071.52

Erdem, A., \& Uzal, G. (2017). An investigation of teachers' professional development needs in technology assisted physics teaching with respect to some variables. The Journal of International Social Research, 10(54), 710-718. https://doi.org/10.17719/jisr.20175434637

Erdem, A., \& Uzal, G. (2018). Principals' views about the use of technology on the improvement of physics education in high schools. The Journal of International Social Research, 11(55), 582-592. https://doi.org/10.17719/jisr.20185537231

Erdem, A., Uzal, G., \& Saka, M. (2018). High school students' proficiency perceptions to the usage of technology products at physics lessons. TOJET: The Turkish Online of Educational Technology, 17(2), 55-67.

Ersoy, Y. (1992). A study on the education of school mathematics and science teachers for information society. METU Education Report, 1, 39-54. Ankara: ODTU Faculty of Education Pub.

Ersoy, Y. (2002). Professional development of mathematics and science teachers: Issues, needs and models. First International Conference on Education: Changing Time, Changing Needs, May 8-10, 2002. KKTC: Eastrean Mediterranean Uni Pub.

Genc, M., \& Genc, T. (2013). Following the Professional Developments of Teachers: Fatih Project Example. Journal of Kirsehir Education Faculty, 14(2).

Gorhan, M. F., \& Oncu, S. (2015). The interactive board in the eyes of teachers and principal: a case study on perceived ease of use and usefullness. Journal of Teacher Education and Educators, 4(1), 53-77.

Harwood, W. S., \& McMahon, M. M. (1997). Effects of integrated video media on student achievement and attitudes in high school chemistry. Journal of Research in Science Teaching: The Official Journal of the National Association for Research in Science Teaching, 34(6), 617-631. https://doi.org/10.1002/(SICI)1098-2736(199708)34:6<617::AID-TEA5>3.0.CO;2-Q

Henning, E. (1994). In-service education for unqualified teachers: suggestions for an alternative model. South African Journal of Education, 21(6), 595-609.

İsci, T. G., \& Demir, S. B. (2015). The use of tablets distributed within the scope of FATIH Project for education in 
Turkey (is FATIH Project a fiasco or a technological revolution?). Universal Journal of Educational Research, 3(7), 442-450. https://doi.org/10.13189/ujer.2015.030703

Jacobs, D. B. (2012). Professional Development of Japanese Science and Physics Teachers and Japanese Approach in Professional Development: Lesson Study. Ankara University Journal of Educational Sciences, 45(2), 33-54. https://doi.org/10.1501/Egifak_0000001252

Kalelioglu, F., \& Altin, H.M. (2013). Evaluation of the Fatih Project By School Administrators. Retrieved from http://dokuman.bilgisayardersi.net/wp-content/uploads/2014/05/M15-Fatih-Projesinin-Okul-Y\%C3\%B6neticileriTaraf\%C4\%B1ndan-De\%C4\%9Ferlendirilmesi.pdf

Karasar, N. (1999). Scientific Research Method (9 $9^{\text {th }}$ Edition). Ankara: Nobel Broadcast Distribution.

Kayaduman, H., Sirakaya, M., \& Seferoglu, S. S. (2011). Investigation of "Increasing opportunities and improvement of technology" project in terms of teacher competencies. Academic Informatics, 11, 123-129.

Kolcak, D. Y., Mogol, S., \& Unsal, Y. (2014). A comparison of the effects of laboratory method and computer simulations to avoid misconceptions in physics education. Education and Science, 39(175). https://doi.org/10.15390/EB.2014.2052

MNE Department of Education Research and Development [EARGED]. (1999). Curriculum Lab Schools MLO Model (1st Edition). Ankara: National Education Publishing House. MNE General Directorate of Educational Technologies (2012). About the movement to increase opportunities in education and improve technology (FATIH) Project. Retrieved from: http://fatihprojesi.meb.gov.tr/about.html

Odabas, H. (2004). Use of the internet-based distance learning model in higher education programs for information services. Inside the saga of librarianship (pp 121-139) (1 ${ }^{\text {st }}$ Edition). Ankara: Ankara University, Faculty of Language History and Geography, Department of Information and Document Management. Ornek, F., Robinson, W. R., \& Haugan, M. P. (2008). What Makes Physics Difficult?. International Journal of Environmental and Science Education, 3(1), $30-34$

Ozkan, A., \& Deniz, D. (2014). The views of secondary education teachers on FATIH Project. Ege Educational Journal, 15(1), 161-175. https://doi.org/10.12984/eed.03604

Pamuk, S., Cakir, R., Ergun, M., Yilmaz, H. B., \& Ayas, C. (2013). The use of tablet PC and interactive board from the perspectives of teachers and students: Evaluation of the FATIH Project. Educational Sciences: Theory \& Practice, 13(3), 1799-1822.

Peled, Y., Kali, Y., \& Dori, Y. J. (2011). School principals' influence on science teachers' technology implementation: A retrospective analysis. International Journal of leadership in Education, 14(2), 229-245. https://doi.org/10.1080/13603124.2010.524249

Ruba, P. A. (1985). Chemistry teachers inservice needs: are they unique. Journal of Chemical Education, 58(5), 430-431. https://doi.org/10.1021/ed058p430

Sarimanoglu-Ucar, N. (2018). Evaluation of the use of information technology tools distributed to schools within the scope of the Fatih Project. MEB General Directorate of Innovation and Educational Technologies. Retrieved from yegitek.meb.gov.tr/meb_iys_dosyalar/2018_11/06102826_NYHAN_YEZT.pdf

Saritepeci, M., Durak, H., \& Seferoglu, S. S. (2016). Examination of teachers' in-service training needs in the field of instructional technology: An evaluation in light of applications implemented at FATIH project. Turkish Journal of Computer and Mathematics Education, 7(3), 601-620. https://doi.org/10.16949/turkbilmat.277873

Smith, H. J., Higgins, S., Wall, K., \& Miller, J. (2005). Interactive Whiteboards: Boonor Bandwagon? A Critical Review of The Literature. Journal of Computer Assisted Learning, 21(2), 91-101. https://doi.org/10.1111/j.1365-2729.2005.00117.x

Tekin, Meral (1996). Radio and Television in Adult Learning. ( $1^{\text {st }}$ Edition ). Ankara: Yuksel Printing.

Turan, S. (2002). The role of the education administrator in the effective use of technology in school management. Journal of Educational Administration, 30, 271-281.

Turel, Y. K. (2012). Teachers' negative attitudes towards interactive whiteboard use: Needs and problems. Ilkögretim Online, 11(2), 423-439. Retrieved from http://ilkogretim-online.org.tr/index.php/io/article/view/1504/1360.

Wilmore, D., \& Betz, M. (2000). Information technology and schools: The principal's role. Educational Technology and Society, 3(4), 12-19.

Yenice, N. (2003). The effect of computer aided science instruction on students' attitudes towards science and 
computers. TOJET, 2(4). Retrieved from http://www.tojet.net/articles/v2i4/2412.pdf

Yigit, N. (2004). Effects of computer assisted applications on success in physics teaching. Journal of National Education, 161, 160-171.

Yigit, N., \& Alev, N. (2017). Technology-assisted physics teaching. In A. I. Sen \& A. R. Akdeniz (Eds), Physics Teaching/ Theoretical Knowledge and Sample Activity Applications (pp.469-497). Ankara: A Pegem Academy. https://doi.org/10.14527/9786052410646.17

Yigit, N., Alev, N., Bülbül, M. Ş., \& Bursal, M. (2008). Examining the effectiveness of a service training course which is themed to information and communication technology (ITC) and material development. Paper presented in VIII.National Science and Mathematics Education Congress in Bolu Abat Izzet Baysal University. August, 27-29, 2008 .

Zhang, M., Parker, J., Koehler, M. J., \& Eberhardt, J. (2015). Understanding in service science teachers' needs for professional development. Journal of Science Teacher Education, 26(5), 471-496. https://doi.org/10.1007/s10972-015-9433-4

\section{Copyrights}

Copyright for this article is retained by the author(s), with first publication rights granted to the journal.

This is an open-access article distributed under the terms and conditions of the Creative Commons Attribution license which permits unrestricted use, distribution, and reproduction in any medium, provided the original work is properly cited. 